RESEARCH NOTES

\title{
The Lexicographical Notes in Bilingual Dictionaries
}

\section{Las notas lexicográficas en los diccionarios bilingües}

\author{
Li Junying \\ Kazan Federal University (Kazan, Russia) \\ ORCID: https://orcid.org/0000-0002-5049-1894 \\ Rezeda Nurutdinovna Karimullina \\ Kazan Federal University (Kazan, Russia), \\ ORCID: https://orcid.org/0000-0002-0548-9445 \\ Sun Miao \\ China University of Petroleum (East China) \\ ORCID: https://orcid.org/0000-0001-8545-7613
}

Received 09-08-20 Revised 10-10-20

Accepted 20-12-21 On line 02-17-21

\section{* Correspondence}

Email: lijunying@yandex.ru

\section{Citation:}

\footnotetext{
Li Junying, Rezeda Nurutdinovna Karimullina, \& Sun Miao. (2021). The Lexicographical Notes in Bilingual Dictionaries. Propósitos y Representaciones, 9(SPE2), e1006. http://dx.doi.org/10.20511/pyr2021.v9nSPE2.1006
} 


\section{Summary}

Dictionary notes play an important role in description of a title unit. A note is an abbreviated word or phrase which gives a certain characteristic to the language unit. Traditionally, different types of notes are distinguished: grammatical, stylistic, sectoral, chronological, etc. The object of this research is a lexicographic note which can be justified if it demarks the usage sphere and language peculiarities of the title unit. The material for the research is bilingual (Russian-Tatar and RussianChinese) dictionaries of various types of the end of the $20^{\text {th }}$ - beginning of the $21^{\text {st }}$ centuries. The paper presents the results of comparative analysis of the notes system in bilingual dictionaries. The study revealed the following: 1) when lexical units are supplied with notes, the authors and compilers of bilingual dictionaries, as a rule, use the data from thesauri of the entry language, though not always consistently; 2) stylistic notes (разг., груб., бранн., сниж., пренебр., презр., etc.) do not have distinct boundaries, thus, a user may have difficulties seeing the difference between the properties; 3 ) the problem of singularia tantum and pluralia tantum words should be specially highlighted, namely, if one meaning of a word is singularia tantum and another is pluralia tantum; 4) a certain group of notes is rare in the analyzed dictionaries, for example, statistical notes, the notes pointing out the dialectical character of the described unites, etc. Terminological notes should be used only for describing polysemantic words to distinguish between their meanings and homonyms; 5) when using lexicographic notes, one of the linguography principles is often violated - to describe similar things in a similar way.

Key words: lexicographical note, bilingual linguography, microstructure, bilingual dictionary, dictionary entry.

\section{Resumen}

Las notas del diccionario juegan un papel importante en la descripción de una unidad de título. Una nota es una palabra o frase abreviada que da una determinada característica a la unidad de lenguaje. Tradicionalmente se distinguen diferentes tipos de notas: gramaticales, estilísticas, sectoriales, cronológicas, etc. El objeto de esta investigación es una nota lexicográfica que puede justificarse si delimita el ámbito de uso y las peculiaridades lingüísticas de la unidad de título. El material para la investigación son diccionarios bilingües (ruso-tártaro y ruso-chino) de varios tipos de finales del siglo XX - principios del siglo XXI. El artículo presenta los resultados del análisis comparativo del sistema de notas en diccionarios bilingües. El estudio reveló lo siguiente: 1) cuando se suministran notas a las unidades léxicas, los autores y compiladores de diccionarios bilingües, por regla general, utilizan los datos de los tesauros de la lengua de entrada, aunque no siempre de forma coherente; 2) las notas estilísticas (разг., Груб., Бранн., Сниж., Пренебр., Презр., Etc.) no tienen límites distintos, por lo que un usuario puede tener dificultades para ver la diferencia entre las propiedades; 3) debe destacarse especialmente el problema de las palabras singularia tantum y pluralia tantum, es decir, si un significado de una palabra es singularia tantum y otro es pluralia tantum; 4) cierto grupo de notas es raro en los diccionarios analizados, por ejemplo, notas estadísticas, las notas que señalan el carácter dialéctico de las unidades descritas, etc. Las notas terminológicas deben usarse solo para describir palabras polisemánticas para distinguir entre sus significados y homónimos; 5) cuando se usan notas lexicográficas, a menudo se viola uno de los principios de la lingüística: describir cosas similares de manera similar.

Palabras clave: nota lexicográfica, lengua bilingüe, microestructura, diccionario bilingüe, entrada de diccionario.

\section{Introduction}

The main structural unit of a dictionary - a dictionary entry - consists of a title unit and its description, including such characteristics as etymological, encyclopedic, stylistic, illustrative, and others (see (Berkov, 2004; Dubichinskiy, 2009; Gafiyatova \& Solnishkina, 2015; Xiangqing Wei et al., 2014; Halpern, 2016) and others). 
A significant role in describing title units is played by dictionary notes. "A note is a word (less often a phrase), predominantly given in an abbreviated or conditional (symbolic) form and giving a certain characteristic to a word or phrase" (Berkov, 2004).

Traditionally, in linguographic practice the following types of notes are distinguished: grammatical, lexical semantic, functional-stylistic, stylistic, emotional-expressive, chronological, statistical, prohibitive, restrictive, etc. (Dubichinskiy, 2009; Tsyrenov, 2014). Many researchers justly assert that a dictionary note allows integrating lexical, grammatical, and stylistic characteristics (see (Budykina, 2019; Nesova, 2014) and others).

\section{Methods}

The study uses methods of linguistic description, contrastive and comparative method.

\section{Results and Discussion}

The research area is the microstructure of lingual reference books; the research object is the zone of notes. The sources are bilingual (Russian-Tatar and Russian-Chinese) dictionaries of various types of the end of the 20th - beginning of the 21 st centuries:

Makhnutov M.I. Learners' Russian-Tatar dictionary: manual for learners. $-3^{\text {rd }}$ edition, revised.- Kazan: Tatar Book Publishers, 1989. - 408 p. (further - LRTD).

Ganiev F.A. (ed.), Gaffarova F.F. Russian-Tatar dictionary. $-2^{\text {nd }}$ edition, revised and completed. - Kazan: Tatar Book Publishers, 2001. - 208 p. (further - RTD).

Abdullin I.A., Ganiev F.A. (ed.), Mukhamadiev M.G., Yunaleeva R.A. Tatar-Russian dictionary: about 25000 words. $-4^{\text {th }}$ edition, corrected. - Kazan: Tatar Book Publishers, 2004. 487 p. (further - TRD).

Huan Suhua, Lyu Guanzhun. Linguo-culture dictionary of the Russian language.Zhengzhou. 2005. - 916 p. (further - LCDRL).

Baranova Z.I., Kotov A.V. Grand Russian-Chinese dictionary. $-6^{\text {th }}$ edition, stereotyped. Moscow: Zhivoy yazyk, 2008. - 568 p. (further - GRCD).

The following notes can be distinguished in the analyzed dictionaries:

Lexical (about a person, about transport, etc.); for example, норка $<\ldots>$ (животное) $<\ldots>$; печь I < ..> (для отопления $)<\ldots>$; сдавленный $($ о голосе, о крике $)<\ldots>$ in GRCD.

Grammatical (indicating a verb aspect, transitivity / intransitivity, etc.): for example, капризничать, наст. -аю, -аешь, несов. '<...' ' in LRTD etc.

According to some researchers, in bilingual dictionaries one should lay special emphasis on the problem of singularia tantum and pluralia tantum words. At that, such cases should not be marked if the translation equivalents also lack the singular or plural form. However, the cases of difference with the entry language should be marked. For example, in RTD for pluralia tantum lexemes, such as брюки, дрова etc., the note только мн. is given for the left part of the vocabulary only.

Special attention should be paid to a case when one meaning of a word is singularia tantum and another is pluralia tantum. For example, the unit долг is presented in the following way in the same dictionary:

долг $м$ 1. бурыч; гражданский долг гражданлык бурычы 2. бурыч, ђќђт; взять в долг бурычка алу. 
Semantic (перен., прям. еtc.): for example, запрячь < ..> прям., перен. <..> in RTD etc.

If the title polysemantic word in the entry language corresponds to just one equivalent, then, as a rule, separate meanings are not distinguished and the note в разных значениях is given; for example: белешмә < ..> в разн. знач. квартал < ..> (TRD). According to V.P. Berkov, this note should be used only if "all meanings of the word in the entry language are conveyed with one and the same equivalent" (Berkov, 2004), that is why the following usage of this note cannot be considered rightful:

жи || $\mathbf{T ь}<\ldots>$ 1. в разн. знач. яшђњ < ..> 2. перен. булу, яшђњ < ..> (RTD).

Functional-stylistic, including terminological (газетн., офиц., спеи., хим., тех., etc.). There is an opinion in linguography, that terminological notes are not informative, as they accompany not only terms but ordinary words too, and most often inconsistently. For example, in GRCD the lexemes клещ, хамелеон are given with notes зоол., while the words аллигатор, жираф, паук - without notes.

The absence of a note next to a unit, which meaning is well known to an average user of the dictionary, does not reduce the amount of information conveyed. As for the units, which meaning is unknown or unclear, the dictionary compiler gives not a note but a comment; see in RTD:

футурология ж футурология (килђчђкне алдан књрњ законнары цђм методлары турындагы фђн).

There is an opinion that terminological notes should be used only when describing polysemantic words to distinguish between different meanings and homonyms (Berkov, 2004; Bergenholtz \& Tarp, 1995):

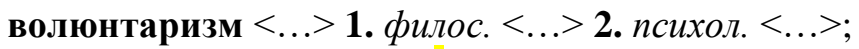

кран II $<\ldots>$ mex. $<\ldots>$ in RTD.

A special group of functional-stylistic notes are the ones pointing out the dialectic character of the described units:

падаль обл. <...>; старый гриб обл. < ..> in LCDRL;

баштан $м$ диал. <..>; жито $с$ диал. <...> in RTD.

Some researchers classify stylistic notes into a) stylistic notes proper (including книюн., разг., фольк., etc.), b) notes indicating the degree of "seriousness" (шутл., ирон., etc.), and c) notes indicating the degree of "rudeness" (груб., вульг., etc.). As a rule, when attributing notes to lexical units, the authors and compilers of bilingual dictionaries use the data from thesauri of the entry language. For example, in LCDRL lexemes have the same features as in (Kuznetsov, 1998): агнец книжн. <.. >, барахляный разг, сниж. <... , etc.

Quite often, the authors do not rely on the information from monolingual thesauri for interpretations. For example, a stylistic note is given for a number of words, while there is no such characteristic in the Russian thesaurus:

LCDRL - нить $<\ldots>$ Ариаднина нить книжн. $<\ldots>$; оборотиться $<\ldots>$ 1. Устар., разг. 'Повернуть голову, туловище в сторону, назад. 2. <...>;

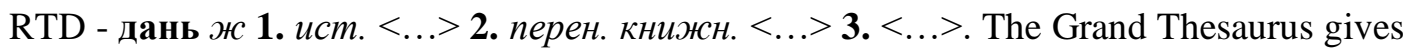
the note for the last meaning only: дань $\langle\ldots>$ 4. Жарг. $<\ldots>$.

Some dictionaries allow certain inaccuracies regarding stylistic notes. Sometimes the authors give a note разг. to units fully used in neutral style: примелькаться in LCDRL; кепка, керосинный in RTD, etc.

In some cases, a note accompanies the described unit in general, while only one meaning belongs to colloquial style; see, for example, in RTD: 

кабару $<\ldots>^{6}$.

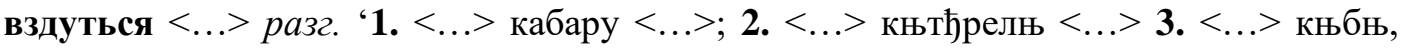

In The Grand Thesaurus, the note pазг. is given to only one meaning:

вздуться <...> 1. Подняться от дуновения ветра <...> 2. Увеличиться в объёме; раздуться, вспухнуть <...> 3. Образовать вздутие; покрыться буграми <...> 4. Разг. Чрезмерно повыситься, увеличиться (о ценах, тарифах еtс.) <...>

In some bilingual dictionaries the note книжн. (bookish style) is interpreted broadly, including высокий стиль, народно-поэтический, еtс.:

забвени $\| \mathbf{e}<\ldots>$ 1. книжн. <..> [RTD]. Compare in (Kuznetsov, 1998): забвение, забвенье $<\ldots>$ 1. устар. $и$ высок. $<\ldots>$.

Evaluative notes are usually interpreted in linguography as negative ones - неодобр., презр., пренебр., etc. Specialists justly mark that the difference between these evaluative characteristics is not always clear enough. For example, in RTD a unit мироед has a note презрит., while in The (Kuznetsov, 1998) the unit мироед has a note разг. Compare presentation of a lexeme дубина in various linguographic sources:

in RTD - дубина $<\ldots>$ 1. $<\ldots>$ 2. бранн. $($ о человеке $)<\ldots>$;

in GRCD - дубина 1. <..>2. разг. (о тупом человеке)

in LCDRL - дубина 1. <..> 2. Разг., сниж. 'о высоком долговязом человеке' < ..> 3. Разг., сниж. 'о бестолковом, тупом человеке' <...

As a rule, the given evaluative notes in bilingual dictionaries coincide with the characteristics given in monolingual reference books.

In the analyzed dictionaries, there are almost no positive evaluative notes, like одобр., noчmum., etc. As a rule, such characteristic is given descriptively; for example, in TRD:

ага $<\ldots>$ '1. <..> 2. <..> 3. прибавляется к мужским именам при почтительном обращчении или упоминании о ком-л.';

агай <..> 'дядя, дядюшка, дяденька (вежливое обращение к старшему мужчине)‘ etc.

Chronological notes (ycmap., ucmop., etc.). In the analyzed dictionaries, the following is observed:

A) temporal characteristic are given in bilingual dictionaries while lacking in The (Kuznetsov, 1998): богоискательство, боярин, вельможа, воевода, дань, декабрист, оруженосец, целование, черносотенец, шлем, etc. [RTD].

B) in some bilingual dictionaries, these notes are lacking for a number of words (бремя, депеша, феодал, etc.), while in The (Kuznetsov, 1998) the same units are given with notes.

In our opinion, it is inacceptable to omit such notes in learners' dictionaries, as their aim is to help language learners to understand fiction and popular science books.

Statistical (or frequency) notes (редко, реже, малоупотр., etc.). These notes are very rarely used in bilingual linguography. The probable reason is that such units are not included into the vocabulary.

Prohibitive (не ynomp. etc.); for example, in [LRTD]:

болеть ${ }^{2}$, наст. 1 и 2 л. не употр. <...>;

накрениться, буд. 1 и 2 л. не употр. <..>, etc.

Restrictive (только мн., только несов., etc.):

in $[\mathrm{LRTD}]$ - брюки $<\ldots>$ только мн. $<\ldots>$; вместимость $<\ldots>$ только ед. $<\ldots>$, 
in RTD - перила $<\ldots>$ только мн. $<\ldots>$; мал||ый $\mathbf{I}<\ldots>$ 3. только кратк. ф. мал, мала, мало $<\ldots>$, etc.

Unfortunately, inconsistent usage of notes is frequent. In [LCDRL] the note уменьи. is given for units орешек, щетинка, рыльце, etc., while words оливка, блюдечко, веревочка, лампочка, etc. do not have this note. Similar type words are given with a sectoral note and without it. For example, in GRCD there are notes for гиппопотам зоол., калий хим., магний хим. and no notes for мотылек, висмут, вольфрам, etc.

\section{Conclusion}

The study researched one of the areas of the microstructure of a language reference book - the zone of notes.

The study of the Russian-foreign language reference books revealed that: 1) when lexical units are supplied with notes, the authors and compilers of bilingual dictionaries, as a rule, use the data from thesauri of the entry language, (for example, the notes system in GRCD coincides with that in (Kuznetsov, 1998)), though not always consistently; 2) stylistic notes (разг., груб., бранн., сниж., пренебр., презр., etc.) do not have distinct boundaries, thus, a user may have difficulties seeing the difference between the properties; 3) the problem of singularia tantum and pluralia tantum words should be specially highlighted, namely, if one meaning of a word is singularia tantum and another is pluralia tantum; 4) a certain group of notes is rare in the analyzed dictionaries, for example, statistical notes, the notes pointing out the dialectical character of the described unites, etc. Terminological notes should be used only for describing polysemantic words to distinguish between their meanings and homonyms; 5) when using lexicographic notes, one of the linguography principles is often violated - to describe similar things in a similar way.

\section{Conclusions}

Thus, notes convey additional information about the title unit, the character of its semantics and usage.

Through stylistic, emotional-expressive characteristic of a word and its sphere of usage, the "Usage features" parameter is manifested. Parametrical data allow revealing what data about a dictionary unit are presented in dictionaries and in what amount and form, as well as to make observations and conclusions about the informational completeness and quality of the existing linguographic sources (see in more detail in (Karimullina \& Karimullina, 2018)).

\section{Acknowledgements}

\section{The work is performed according to the Russian Government Program of Competitive Growth of Kazan Federal University.}

\section{References}

Bergenholtz, H., \& Tarp, S. (Eds.). (1995). Manual of specialised lexicography: the preparation of specialised dictionaries (Vol. 12). John Benjamins Publishing.

Berkov, V.P. (2004). Bilingual lexicography: tutorial. Moscow: AST: Astrel, 236 p.

Budykina, V.G. (2019). On types and functions of dictionary notes in the Russian and foreign lexicographic practice. Philological Studies. Issues of theory and practice, 4. URL: https://cyberleninka.ru/article/n/o-vidah-i-funktsiyah-slovarnyh-pomet-v-rossiyskoy-izarubezhnoy-leksikograficheskoy-praktike (access date: 03.07.2020).

Dubichinskiy, V.V. (2009). lexicography of the Russian language: tutorial.- Moscow: Flinta: Nauka,- 432 p.

Gafiyatova, E.V., \& Solnishkina, M. I. (2015). Multi-word lexical entries in lsp dictionaries: Theoretical considerations. Journal of Language and Literature, 6(2), 71-75. 
Halpern, J. (2016). Compilation techniques for pedagogically effective bilingual learners' dictionaries. International Journal of Lexicography, 29(3), 323-338.

Karimullina, R.N., \& Karimullina, G.N. (2018). Bilingual linguographic sources: Parametric analysis [Fuentes lingvograficas bilingves: Analisis paramatrico]. Opcion, 34(14), 824-839

Kuznetsov, S.A. (ed.). (1998). Grand Thesaurus of the Russian Language. Saint Petersburg: Norint.

Nesova, N.M. (2014). Dictionary notes: comprehensive representation of a word and a lexeme in comparative aspect. Vestnik RUDN. Series: Language theory. Semiotics. Semantics, 2. URL: https://cyberleninka.ru/article/n/slovarnye-pomety-kompleksnoe-predstavlenieslova-i-leksemy-v-sopostavitelnom-aspekte (дата обращения: 03.07.2020).

Tsyrenov, B.D. (2014). Lexicographic notes in Mongolian-Russian dictionaries. Vestnik BGU, 8. URL: https://cyberleninka.ru/article/n/leksikograficheskie-pomety-v-mongoloyazychnorusskih-slovaryah (access date: 03.07.2020).

Xiangqing Wei et al. (2014). Lexicography in China (1978-2008). Beijing: The Commercial Press,- VI + $445 \mathrm{p}$. 